ANADOLU, J. of AARI

ISSN: 1300-0225 (Print)

E-ISSN: 2667-6087 (Online)

2019, 29 (2): 85-92

DOI: $10.18615 /$ anadolu.660232

\title{
Bal Arılarında Kışlama Öncesi Farklı Beslemenin Koloni Gelişimine Etkileri
}

\author{
Mustafa KÖSOĞLU ${ }^{1^{*}}$ (D) Erkan TOPAL ${ }^{2}$ Rahşan İvgin TUNCA ${ }^{3}$ \\ Banu YÜCEL ${ }^{4}$ id Ismail YILDIZDAL ${ }^{5}$ \\ ${ }^{1,2,5}$ Ege Tarımsal Araştırma Enstitüsü Müdürlüğ̈̈, Menemen-İzmir/TURKEY \\ ${ }^{3}$ Muğla Sitkı Koçman Üniversitesi, Ula Meslek Yüksek Okulu, \\ Bitkisel ve Hayvansal Üretim Bölümü, Arıcılı Programı, Ula-Muğla/TURKEY \\ ${ }^{4}$ Ege Üniversitesi Ziraat Fakültesi Zootekni Bölümü, Bornova-İzmir/TURKEY \\ ${ }^{1}$ https://orcid.org/0000-0001-6616-089X $\quad{ }^{2}$ https://orcid.org/0000-0002-1398-4390 $\quad{ }^{3}$ https://orcid.org/0000-0003-0745-6732 \\ ${ }^{4}$ https://orcid.org/0000-0003-4911-7720 $\quad{ }^{5}$ https://orcid.org/0000-0002-4949-6807 \\ * Corresponding author (Sorumlu yazar): mustafa.kosoglu@gmail.com \\ Received (Geliş tarihi): 08.05.2019 Accepted (Kabul tarihi): 09.08.2019
}

ÖZ: Bal arılarının besin ihtiyaçlarının bilinmesi ve doğal floral kaynakların yetersiz kaldığ durumlarda ek beslemenin yapılması koloninin sürekliliğini sağlamada önemlidir. Çalışma tesadüf parselleri deneme desenine göre; karışık bahar poleni, piyasada satılan ticari arı keki, bal ve şeker şurubu ile beslenen her grupta 6 adet koloni yer alacak şekilde düzenlenmiş toplam 24 koloniden oluşturulmuştur. Araştırmada, arılı çerçeve sayısı, yavrulu alan, kışlama yeteneği, polen depolama alanı ve kışlama öncesi Nosema spp. durumu incelenmiştir. Denemede polen grubu arılı çerçeve sayısı, yavrulu alan ve polen depolama alanı bakımından önemli çıkarken $(p<0,05)$ kışlama yeteneğinde gruplar arası istatistiksel farklılık tespit edilememiştir. Gruplar içerisinde en yoğun Nosema spp. yükü arı keki ile besleme yapılan grupta tespit edilmiştir. Bal arıları beslenmesinde polen vazgeçilmez bir kaynaktır. Doğada az olduğu dönemlerde taze polenin ek beslemede kullanılmasının koloni gelişiminde ve sağliğında etkili olduğu ortaya konulmuştur.

Anahtar Kelimeler: Bal arısı, beslenme, polen, arı keki, koloni performansı, Nosema spp.

\section{Effects of Different Nutritions on Colony Development in Honey Bees Before Wintering}

ABSTRACT: It is important to know the nutritional requirements of honey bees and to provide additional feeding in case of insufficient natural floral sources in honey bees for continuity of the colony. The study was composed of four groups, and total 24 colonies according to randomized plot design: fed by mixed spring pollen, commercially sold bee cake, honey and sugar syrup, and each group have consisting of six colonies. In this research, the number of frame/worker bee, brood rearing area, wintering ability, pollen storage area and Nosema spp. before wintering were examined. In this study, pollen group, number of frame/worker bee, brood rearing area, and pollen storage area were statistically significant $(p<0.05)$, and there is no statistical difference between groups in wintering ability. Among the groups, highest Nosema spp. load was found in the group "fed with bee cake". Pollen is an important source of honey bees nutrition. It has been shown that the use of fresh pollen in supplementary feeding is effective in colony development and health when it is rare in nature.

Keywords: Honey bee, nutrition, pollen, bee cake, colony performance, Nosema spp. 


\section{GíRiş}

Bal arısı bireylerinin sağlığı ve koloninin gelişimi, kovan içindeki besin maddelerine bağlıdır. Bal arıları nektardan karbonhidrat ve polenden de başta protein olmak üzere diğer tüm besin madde ihtiyaçlarını sağlamaktadırlar (Brodschneider ve Crailsheim, 2010). Floranın yetersiz olduğu dönemlerde arıları beslemek için bal yerine sükroz kullanılabilirken, polen için tam bir ikame bulunamamıştır. Bu nedenle polen, koloni sağlığının korunmasında sinırlayıcı bir faktör haline gelmektedir (Huang, 2012; Shumkova ve ark., 2017). Ani iklim değişimleri florayı etkilediğinde kolonilerin yeni floral kaynaklara nakledilmesi ya da ek besleme ile bu sürecin atlatılması gerekmektedir (Mata, 2018). Polen, özellikle nektar kaynaklarının azalmasından sonra koloni gelişiminin tekrar sağlanabilmesi ve kışlatmaya kuvvetli girilmesi açısından oldukça önemlidir. Bu durumlarda üretici kolonilerini polen kaynakları, polen ikame kekleri, şeker şurubu veya bal ile beslemektedir. Piyasadaki hazır keklerin kalitesi ve içeriği çoğu kez istenilen düzeye sahip değildir. Bal arılarında polenle beslemenin yaygınlaştırılması arı sağlığı açısından bir zorunluluk olarak görülmektedir. Birçok ülkede bal arılarını değişik protein ve karbonhidrat kaynakları ile besleme araştırmaları yürütülmektedir (Peters ve ark., 2010; Saffari ve ark., 2010; Kumar ve ark., 2013; Sihag ve Gupta, 2013; El-Wahab ve ark., 2016; Sena ve ark., 2017; Yang ve ark., 2017; Eshbah ve ark., 2018; Koru, 2018; McAulay, 2018; Nicolson ve ark., 2018).

Genel olarak kötü ve yetersiz beslenme, kolonilerde viral ve fungal hastalıların ortaya çıkışına zemin hazırlayabilmektedir (Dolezal ve Toth, 2018). Doğal besin ile beslenen bal arıs1 kolonilerinin, protein takviyeleri ile beslenenlere oranla daha düşük patojen yükleri olduğu ve kıştan kuvvetli çıktıkları bildirilmiştir (DegrandiHoffman ve ark., 2016).

Nosema spp. yetişkin arılarda oldukça yaygın bulunmakta ve kışlama performansını etkilemektedir. Protein yetersizliği Nosema spp. düzeyinin artmasının ana nedenidir. Polen ile beslenen arılarda Nosema spp. yüküne rağmen kış kaybının gerçekleşmediği belirtilmektedir (Jack ve ark., 2015). Sonbaharın sonlarında ve kış mevsiminde kolonilerde Nosema spp. yükü yüksek seviyelere ulaşabilmektedir. Sonbahar, Nosema spp. hastalığının gelecek ilkbaharda önlenmesi adına koloni yönetimi bakımından yılın önemli bir zamanıdır. Ilıman bölgelerde Nosema enfeksiyonları ciddi bir problem olarak değerlendirilmeli ve bu bölgelerde bal arıs1 kolonilerinin üretim performans1 üzerindeki olumsuz etkileri göz ardı edilmemelidir (Fries, 1993; Rice, 2001; Somerville, 2005). Bu anlamda sağlık ve beslenme ilişkisi oldukça önemlidir. Yetersiz polenle beslenme, işçi arılarda Nosema spp. ve pestisitlere karşı duyarlılığının artmasına, virüslere karşı direncin azalmasına neden olmaktadır. Diğer taraftan polifloral polen ile beslenme, arıların bağışıklık ile ilgili enzim aktivitelerini arttırarak stres etmenlerine karşı daha dirençli hale gelmesini sağlamaktadır. Kolonilerin kaliteli ve yeterli polenle beslenmesi, bal arısının Nosema ceranae veya ektoparazitik akar ve varroaya karşı direncini arttırmaktadır (Huang, 2012).

$\mathrm{Bu}$ çalışma ile Ağustos-Ekim aylarında üretimi yapılan çam bal1 hasad1 sonras1 zayıflayan kolonilerde ek beslemenin koloni performansi ve kışlatma öncesi Nosema spp. spor düzeylerine etkisinin belirlenmesi amaçlanmıştır.

\section{MATERYAL ve METOT}

Çalışma İzmir İli Menemen İlçesi'nde bulunan Ege Tarımsal Araştırma Enstitüsü Müdürlüğü arılığında

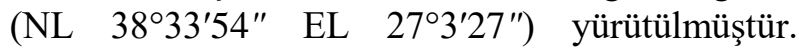
Denemede Efe Arıs1 (Apis mellifera anatoliaca) kullanılmıştır. Koloniler 21 Eylül 2018 tarihinde 3 adet çerçeve (1 adet ballı-polenli, 2 adet kabarmış boş petek) ve $1 \mathrm{~kg}$ paket arıdan oluşturulmuştur. Deneme grupları, her grupta 6 koloni olacak şekilde polen grubu (karışık bahar poleni), arı keki grubu, bal şurubu grubu ve şeker şurubu olmak üzere 4 grup ve toplam 24 koloniden oluşturulmuştur. İlk besleme, deneme materyali oluşturulduğu ilk gün gerçekleştirilmiştir. Araştırma Tesadüf Parselleri Deneme Desenine göre planlanmıştır. Beslemenin gruplar arası koloni performansina etkilerinin belirlenmesi amaciyla sonbahar dönemi 2 ve kışlama sonrası 1 ölçüm yapılmıştır. Beslenme tarihleri, miktarları ve zamanları Çizelge 1 'de verilmiştir.

Beslemede kullanılan polen ve arı kekinin protein oran1 (Fuenmayor, 2009) ve kuru madde oran1 (Adolfo, 1985) Çizelge 2'de verilmiştir. 
Çizelge 1. Grupların besleme zamanı ve miktarı.

Table 1. Feeding time and amounts of groups.

\begin{tabular}{|c|c|c|c|c|c|c|c|c|c|c|c|c|c|c|}
\hline \multirow{3}{*}{$\begin{array}{l}\text { Gruplar* } \\
\text { Groups }\end{array}$} & \multicolumn{14}{|c|}{$\begin{array}{l}\text { Besleme dönemi ve miktarı } \\
\text { Feeding period and amount }\end{array}$} \\
\hline & \multicolumn{2}{|c|}{ 21.09.2018 } & \multicolumn{2}{|c|}{ 24.09.2018 } & \multicolumn{2}{|c|}{28.09 .2018} & \multicolumn{2}{|c|}{04.10 .2018} & \multicolumn{2}{|c|}{15.10 .2018} & \multicolumn{2}{|c|}{02.11 .2018} & \multicolumn{2}{|c|}{22.02 .2019} \\
\hline & $(\mathrm{kg})$ & (lt) & $(\mathrm{kg})$ & (lt) & $(\mathrm{kg})$ & (lt) & $(\mathrm{kg})$ & (lt) & $(\mathrm{kg})$ & (lt) & $(\mathrm{kg})$ & (lt) & $(\mathrm{kg})$ & (lt) \\
\hline $\begin{array}{l}\text { Polen } * * \\
\text { Pollen }\end{array}$ & 1,5 & 9 & 1,5 & 9 & 1,5 & - & 1,5 & 9 & 1,5 & 9 & 1,5 & 9 & - & 3 \\
\hline $\begin{array}{l}\text { Ar1 keki } * * \\
\text { Bee cake }\end{array}$ & 6 & 9 & - & 9 & - & - & - & 9 & 6 & 9 & - & 9 & - & 3 \\
\hline $\begin{array}{l}\text { Bal şurubu *** } \\
\text { Honey syrup }\end{array}$ & - & 9 & - & 9 & - & - & - & 9 & - & 9 & - & 9 & - & 3 \\
\hline Şeker şurubu & - & 9 & - & 9 & - & - & - & 9 & - & 9 & - & 9 & - & 3 \\
\hline
\end{tabular}

*Her grupta 6 koloni olup grubun toplam beslenme miktarları verilmiştir (In each group there are 6 colonies and total consumption of the group is given)

**Polen ve arı keki grubuna ilave şeker şurubu verilmiştir. (Additional sugar syrup was given to pollen and bee cake group).

***Diğer grup sadece bal şurubu ile beslenmiştir (The other group was fed only with honey syrup).

Çizelge 2. Polen ve arı kekinin protein ve kuru madde oranı (\%).

Table 2. Dry matter and protein ratios of pollen and bee cake $(\%)$.

\begin{tabular}{|c|c|c|}
\hline $\begin{array}{l}\text { Besin maddesi } \\
\text { Nutrient }\end{array}$ & $\begin{array}{l}\text { Protein* } \\
\text { Protein } \\
(\%)\end{array}$ & $\begin{array}{c}\text { Kuru madde** } \\
\text { Dry matter } \\
(\%)\end{array}$ \\
\hline Karışık bahar poleni (Mixed spring pollen) & 19,62 & 85,80 \\
\hline Arı keki (Bee cake) & 0,06 & 95,00 \\
\hline
\end{tabular}

* Fuenmayor (2009) ** Adolfo (1985).

Paket arıların kovanlara yerleşiminden yaklaşık 4 hafta sonra popülasyonların tamamen yenilenerek gelişimlerini sürdürdükleri belirlenmiştir (Doğaroğlu, 1987; Öder, 1997; Doğaroğlu, 2009; Kandemir, 2004). Kolonilerin bulundukları bölgedeki nektar kaynakları, iklim koşulları, kışlama durumları göz önünde bulundurularak besleme yapılmıştır (Somerville, 1999; Somerville, 2000; Akyol ve ark., 2006). Besleme boyunca polen grubuna koloni başına 1,5 $\mathrm{kg}$ karışı bahar poleni ve $8 \mathrm{lt}$ şeker şurubu, kek grubuna koloni başına $2 \mathrm{~kg}$ arı keki ve 8 lt şeker şurubu verilmiştir. Bal ve şeker grubuna koloni başına 8 lt bal şurubu ve 8 lt şeker şurubu verilmiștir. Verilen besin miktarlarının tamamı koloni tarafından alınmıștır. Bal ve şeker şurubu 1,7 birim bal ve şeker/1 birim su ile oluşturulmuştur.

\section{Koloni Performansı}

Koloni performans ölçümleri Ekim - Kasım 2018'de birer kez ve Mart 2019'da bir kez olmak üzere toplam 3 kez yapılmıştır.
Arılı çerçeve sayısı (AÇS): Üzeri tamamen ergin arı ile kaplı çerçeve sayısı olarak alınmıştır. Bunun için kovanlarda toplam arılı çerçeve sayısı kayıt altına alınmış ve 3000 arı/çerçeve hesabıyla arı sayısı hesaplanmıştır (Doğaroğlu, 1981; Fıratlı ve Karacaoğlu, 1995; Yücel ve Kösoğlu, 2011).

Yavrulu alan (YA): Açık ve kapalı yavrulu çerçeveler ile açık ve kapalı yavru alanları Puchta yöntemi ile ( $\mathrm{S}=3,14 \times \mathrm{A} / 2 \mathrm{X}$ a/2; $\mathrm{S}$ :alan; A:elipsin uzun ekseni; a:elipsin kısa ekseni) hesaplanmıştır (Fresnaye ve Lensky, 1961; Doğaroğlu, 1981; Doğaroğlu ve ark., 1986; Doğaroğlu ve Ortaç, 1992; Kaftanoğlu ve ark., 1993; Güler ve ark., 1999; Yücel ve Kösoğlu, 2011).

Kışlama yeteneği (KY): Kış girişi arılı çerçeve sayıları (kasım ayı) ve kıştan çıkan arılı çerçeve sayıları farkının 100 ile çarpımı kışlama kabiliyeti olarak belirlenmiştir (Akyol ve ark., 2005).

Polen depolama alanı (PDA): Çerçeve boyutunda $40 \times 20 \mathrm{~cm}$ şeffaf asetata $2 \times 2 \quad \mathrm{~cm}$ 'lik kareler 
çizilerek kare içerisinde yer alan depolanmış polen miktarı belirlenmiştir.

Nosema spp. yükü: Denemede her kovanı temsilen arılık başına 50 tarlacı işçi arı toplanarak laboratuvara getirilmiştir. Nosema spp. yükünün belirlenmesi için hazırlanan homojenatlar için World Organization for Animal Health (OIE) Uygulama kılavuzunun (2008) belirtmiş olduğu yöntem kullanılmıştır (Anonymous, 2018). Hazırlanan homojenatlardaki Nosema spp. spor sayımları hemositometre üzerinde 400x büyütmeli 1şı mikroskobunda gerçekleştirilmiştir (Anonymous, 2018). Sonbahar döneminde yapılan besleme gruplarından alınan arı örneklerinde 3 tekerrür ile sayım yapılmıştır.

\section{Araştırmada Elde Edilen Verilerin Değerlendirilmesi}

Tesadüf Parselleri Deneme Desenine göre 6 tekerrürlü olarak yürütülen bu çalışmadan elde edilen verilere ait ortalama, standart hata değerleri hesaplanarak, LSD testi uygulanmıştır (Steel ve Torrie, 1980; Yurtsever, 1984).

\section{BULGULAR}

\section{Koloni Performansı}

Genel ortalamalara göre, polen grubu arılı çerçeve sayısı bakımından diğer muamele gruplarından istatistiksel olarak önemli $(\mathrm{P}<0,05)$ düzeyde farklı bulunmuştur (Çizelge 3). Polen grubuna verilen karışık bahar poleninin koloniye pozitif etkisi ile arılı çerçeve sayısını deneme kurulduğu tarihe göre anlamlı derecede arttırdığı belirlenmiştir. Ölçüm tarihlerinde polen dışındaki diğer muamele grupları arasında istatistiksel açıdan önemli bir fark $(\mathrm{P}>0,05)$ bulunmamıştır.

Farklı tarihlerinde arılı çerçeve sayısı (adet) ortalamaları ve ortalamanın standart hata değerleri Çizelge 3'de verilmiştir.

Farklı tarihlerinde yavrulu alan ölçümüne $\left(\mathrm{cm}^{2}\right)$ ait ortalama ve ortalamanın standart hata değerleri Çizelge 4'de verilmiştir.

Çizelge 3. Farklı ölçüm tarihlerinde arılı çerçeve sayısı (adet) ortalama ve standart hata değerleri.

Table 3. The mean values and standart errors for number of frame with worker bees in different measurement dates.

\begin{tabular}{lcccc}
\multirow{2}{*}{$\begin{array}{l}\text { Uygulamalar } \\
\text { Treatments }\end{array}$} & \multicolumn{3}{c}{ Arılı çerçeve sayıs (Adet) } & \multirow{2}{*}{$\begin{array}{c}\text { Genel ortalama } \\
\text { Number of frame with worker bees (No.) }\end{array}$} \\
\cline { 2 - 4 } & 22.10 .2018 & 12.11 .2018 & 01.03 .2019 & \\
\hline Polen (Pollen) & $4,50 \pm 0,09 \mathrm{~A}$ & $5,08 \pm 0,15 \mathrm{~A}$ & $3,83 \pm 0,35 \mathrm{~A}$ & $4,47 \pm 0,13 \mathrm{~A}$ \\
Arı keki (Bee cake) & $3,58 \pm 0,09 \mathrm{~B}$ & $3,58 \pm 0,15 \mathrm{~B}$ & $2,66 \pm 0,35 \mathrm{~B}$ & $3,27 \pm 0,13 \mathrm{~B}$ \\
Bal şurubu (Honey syrup) & $3,50 \pm 0,09 \mathrm{~B}$ & $3,58 \pm 0,15 \mathrm{~B}$ & $2,08 \pm 0,35 \mathrm{~B}$ & $3,05 \pm 0,13 \mathrm{~B}$ \\
Şeker şurubu (Sugar syrup) & $3,41 \pm 0,09 \mathrm{~B}$ & $3,41 \pm 0,15 \mathrm{~B}$ & $1,91 \pm 0,35 \mathrm{~B}$ & $2,91 \pm 0,13 \mathrm{~B}$ \\
\hline CV \% & 6,29 & 9,57 & 32,8 & 9,44 \\
\hline LSD $(0,05)$ & 0,28 & 0,45 & 1,08 & 0,38 \\
\hline
\end{tabular}

†Aynı harfle gösterilen ortalamalar arasında istatistiksel olarak önemli bir fark yoktur $(\mathrm{P} \geq 0,05)$

$\dagger$ Means followed by the same letter within each column are not statistically different $(\mathrm{P} \geq 0.05)$.

Çizelge 4. Farklı ölçüm tarihlerinde yavrulu alan ölçümü $\left(\mathrm{cm}^{2}\right)$ ortalama ve standart hata değerleri.

Table 4. The mean values and standart errors for brood rearing area $\left(\mathrm{cm}^{2}\right)$ in different measurement dates.

\begin{tabular}{|c|c|c|c|c|}
\hline \multirow[t]{2}{*}{$\begin{array}{l}\text { Uygulamalar } \\
\text { Treatments }\end{array}$} & \multicolumn{3}{|c|}{$\begin{array}{l}\text { Yavrulu alan ölçümü }\left(\mathrm{cm}^{2}\right) \\
\text { Brood rearing area }\left(\mathrm{cm}^{2}\right)\end{array}$} & \multirow{2}{*}{$\begin{array}{l}\text { Genel ortalama } \\
\text { General mean }\end{array}$} \\
\hline & 22.10 .2018 & 12.11 .2018 & 01.03 .2019 & \\
\hline Polen (Pollen) & $2324,00 \pm 130,26 \mathrm{~A}$ & $1341,00 \pm 249,51$ & $1535,00 \pm 142,63 \mathrm{~A}$ & $1733,33 \pm 101,43 \mathrm{~A}$ \\
\hline Arı keki (Bee cake) & $1339,25 \pm 130,26 \mathrm{C}$ & $878,50 \pm 249,51$ & $1095,20 \pm 142,63 \mathrm{~B}$ & $1104,31 \pm 101,43 \mathrm{~B}$ \\
\hline Bal șurubu (Honey syrup) & $1775,33 \pm 130,26 \mathrm{~B}$ & $829,66 \pm 249,51$ & $619,80 \pm 142,63 \mathrm{C}$ & $1074,94 \pm 101,43 \mathrm{~B}$ \\
\hline Șeker şurubu (Sugar syrup) & $1588,50 \pm 130,26 \mathrm{BC}$ & $757,33 \pm 249,51$ & $903,16 \pm 142,63 \mathrm{BC}$ & $1083,00 \pm 101,43 \mathrm{~B}$ \\
\hline $\mathrm{CV} \%$ & 18,16 & 64,22 & 33,64 & 19,89 \\
\hline $\operatorname{LSD}(0,05)$ & 384,11 & Ö.D. & 420,57 & 299,08 \\
\hline
\end{tabular}

$\uparrow$ Aynı harfle gösterilen ortalamalar arasında istatistiksel olarak önemli bir fark yoktur $(\mathrm{P} \geq 0,05)$.

$\dagger$ Means followed by the same letter within each column are not statistically different $(\mathrm{P} \geq 0.05)$

$\dagger$ Ö.D. (N.S.): Önemli değil (Non-significant). 
Kışlama öncesi 22.10.2018 tarihinde yapılan birinci ölçümde polen grubu yavrulu alan bakımından 1 . sırada yer alırken, kek grubu 4. sırada yer almıştır (Çizelge 4). Bu farkl1lık istatistik olarak önemli bulunmuştur $(\mathrm{P}<0,05)$. Polen grubu kışa girişte, kıştan çıkışta ve genel ortalamada diğer gruplardan önemli düzeyde daha fazla yavrulu alan gelişimi göstermiştir $(\mathrm{P}<0,05)$. Genel ortalamada ise polen grubu istatistiksel olarak kek, şeker ve bal şurubuna göre yavrulu alan gelişimi bakımından önemli düzeyde yüksek $(\mathrm{P}<0,05)$ bulunmuştur.

Farklı tarihlerinde polen depolama alanı ölçümüne $\left(\mathrm{cm}^{2}\right)$ ait ortalama ve ortalamanın standart hata değerleri Çizelge 5'te verilmiştir.

Polen depolama ölçümü koloninin gelişimi açısından önemli düzeyde veri sağlayan bir parametredir. Polen depolama alanı bakımından polen grubu, genel olarak diğer gruplardan önemli $(\mathrm{P}<0,05)$ düzeyde farklı bulunmuştur (Çizelge 5).

Kışlama yeteneği bakımından sonbahar döneminde besleme ile sağlanan fark kışlama dönemi sonunda korunmuş olup gruplar arası fark istatistiksel olarak önemli bulunmamıştır (Çizelge 6).

\section{Gruplardaki Kolonilerin Nosema spp. Durumu}

Sonbahar döneminde yapılan besleme gruplarından alınan arı örneklerinde 3 paralelle sayım yapılmıştır. Nosema spor varlığ tespit edilmiş olan kovanlara ait veriler Çizelge 7'de verilmiştir.

Her bir besleme grubundan 6 kovandan alınan numunelerde 3 paralelle Nosema spp. spor sayıları Şekil 1'de verilmiştir. En fazla spor miktarının arı keki ile beslenen grupta olduğu gözlenmiştir.

Çizelge 5. Farklı ölçüm tarihlerinde polen depolama alanı $\left(\mathrm{cm}^{2}\right)$ ortalama ve standart hata değerleri.

Table 5. The mean values and standart errors of pollen storage in different measurement dates $\left(\mathrm{cm}^{2}\right)$.

\begin{tabular}{lcccc}
\hline \multirow{2}{*}{$\begin{array}{l}\text { Uygulamalar } \\
\text { Treatments }\end{array}$} & \multicolumn{3}{c}{$\begin{array}{c}\text { Polen depolama alan1 }\left(\mathrm{cm}^{2}\right) \\
\text { Pollen storage area }\left(\mathrm{cm}^{2}\right)\end{array}$} & \multirow{2}{*}{$\begin{array}{c}\text { Genel ortalama } \\
\text { General mean }\end{array}$} \\
\cline { 2 - 4 } & 22.10 .2018 & 12.11 .2018 & 01.03 .2019 & \\
\hline Polen (Pollen) & $465,66 \pm 49,32 \mathrm{~A}$ & $224,50 \pm 52,92$ & $10,16 \pm 1,48 \mathrm{~A}$ & $233,44 \pm 23,19 \mathrm{~A}$ \\
Ar1 keki (Bee cake) & $122,66 \pm 49,32 \mathrm{~B}$ & $55,40 \pm 52,92$ & $8,00 \pm 1,48 \mathrm{AB}$ & $62,02 \pm 23,19 \mathrm{~B}$ \\
Bal şurubu (Honey syrup) & $155,66 \pm 49,32 \mathrm{~B}$ & $57,50 \pm 52,92$ & $3,16 \pm 1,48 \mathrm{C}$ & $72,11 \pm 23,19 \mathrm{~B}$ \\
SSeker şurubu (Sugar syrup) & $223,00 \pm 49,32 \mathrm{~B}$ & $44,25 \pm 52,92$ & $5,00 \pm 1,48 \mathrm{BC}$ & $90,75 \pm 23,19 \mathrm{~B}$ \\
\hline CV \% & 49,97 & 135,87 & 55,37 & 49,58 \\
\hline LSD $(0,05)$ & 145,43 & Ö.D. & 4,38 & 68,39 \\
\hline
\end{tabular}

$\lceil$ †ynı harfle gösterilen ortalamalar arasında istatistiksel olarak önemli bir fark yoktur $(\mathrm{P} \geq 0,05)$.

$\dagger$ Means followed by the same letter within each column are not statistically different $(\mathrm{P} \geq 0,05)$.

$\dagger$ Ö.D. (N.S.): Önemli değil (Non-significant).

Çizelge 6. Grupların kışlama yeteneği.

Table 6 . Wintering ability of groups.

\begin{tabular}{lc}
\hline Uygulamalar & Kişlama yeteneği \\
Treatments & Wintering ability (\%) \\
\hline Polen (Pollen) & $86,78 \pm 6,55$ \\
Arı keki (Bee cake) & $85,51 \pm 6,55$ \\
Bal şurubu (Honey syrup) & $73,11 \pm 6,55$ \\
Şeker şurubu (Sugar syrup) & $78,17 \pm 6,55$ \\
\hline CV \% & 19,85 \\
\hline LSD $(0,05)$ & Ö.D. \\
\hline
\end{tabular}

$\uparrow$ Ö.D. (N.S.): Önemli değil (Non-significant).

Çizelge 7. Grupların kışlama öncesi Nosema spp. varlığı.

Table 7. Presence of Nosema spp. groups before wintering.

\begin{tabular}{ccccc}
\hline Koloniler & Arl keki & Bal şurubu & Şeker şurubu & Polen \\
Colonies & Bee cake & Honey syrup & Sugar syrup & Pollen \\
\hline 1 & + & - & + & + \\
2 & - & - & - & + \\
3 & - & - & - & + \\
4 & - & + & - & - \\
5 & + & + & - & - \\
\hline
\end{tabular}




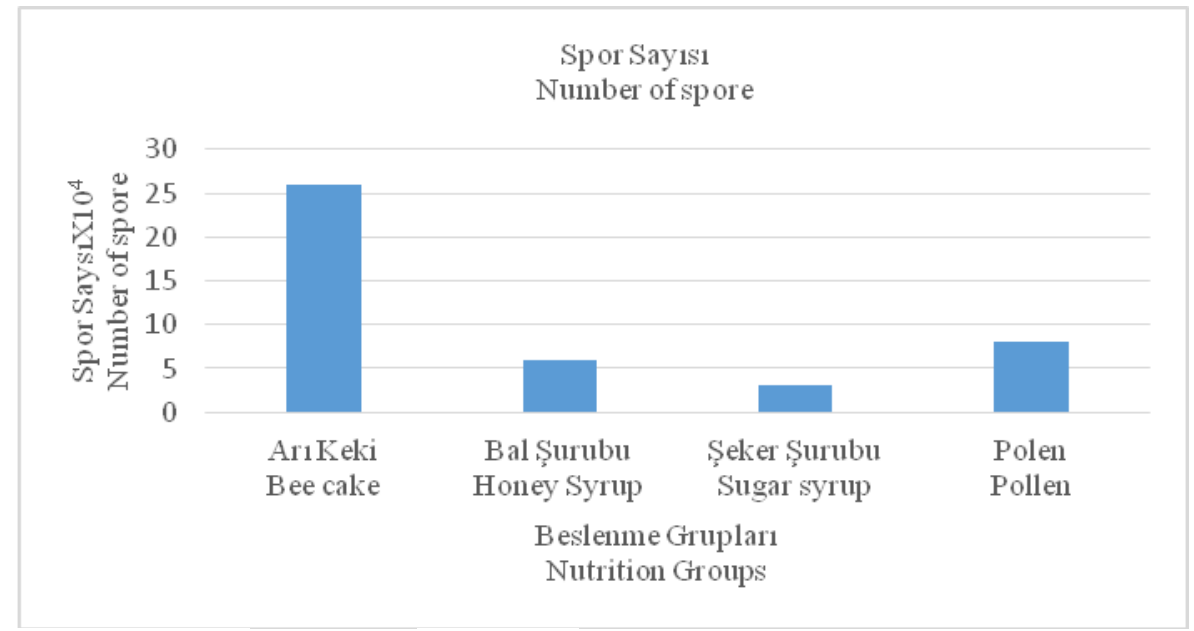

Şekil 1. Grupların Nosema spp. spor sayıları.

Figure 1. Numbers of Nosema spp. spore of groups.

\section{TARTIŞMA ve SONUÇ}

Deneme sonuçlarına bakıldığında polenin tam gida olduğu ve koloninin ihtiyaçlarını tamamen karşıladığı görülmüştür (Huang, 2012). İkinci ölçüm kışlamaya yakın, koloni gelişiminin durduğu süreç (ana arının yumurta atmadığı) olduğundan gruplar arası fark olmadığı tespit edilmiştir. Genel ortalamalara bakıldığında gruplar arası arılı çerçeve, yavrulu alan ve polen depolama alanı bakımından polen grubunun diğer gruplardan istatistik olarak önemli düzeyde farklı olduğu bulunmuştur $(\mathrm{P} \leq 0,05)$. Beslemede protein içeriğinin yüksek olmasının yavrulu alan ve arılı çerçeve sayısını artırdığı daha önce yapılan çalışmalarda ortaya konulmuştur (Şahinler ve Kaya, 2001; Irandoust ve Ebadi, 2013; Gemeda, 2014). Çalışmamızda benzer şekilde polen grubu arılı çerçeve sayısı, yavrulu alan ve polen depolama alanı açısından diğer gruplardan istatistiksel olarak önemli bulunmuştur $(\mathrm{P} \leq 0,05)$. Sonbaharda polenle ek besleme yapılmas 1 hem bu dönemde hem de ilkbaharda arının hızlı gelişmesi açısından yarar sağlamıştır. 01.03.2019 tarihindeki ölçümde bal grubunda yavru alanının düşük düzeyde bulunmasının polen stokunun azlığ ile bağlantılı olabileceği düşünülmüştür. Mevsim dikkate alındığında, muhtemelen polen dıșındaki diğer muamele gruplarında polen düzeyinin düşük olmasına bağlı olarak yavru gelişiminin azaldığı saptanmışıtır.

Kış çıkışı arılı çerçeve sayısı bakımından 01.03. 2019 tarihinde istatistiki olarak fark olmamasına rağmen polen grubu önde görülmektedir. Kışlama öncesi protein ve mineral madde kaynağı olan polen ile besleme, kışlama yeteneğini olumlu etkilerken, koloninin gelişimine yardımcı olmaktadır. Polen grubundaki arıların daha canlı, sağlıklı ve hareketli olduğu gözlemlenmiştir.

Çalışmanın bulgularına göre tüm gruplarda Nosema spp. sporu gözlenmiştir. Sonbahar döneminde Nosema spp. tespit edilse de polen grubunda kışlama performansı, rakamsal olarak daha yüksek gerçekleşmiştir. Buna göre Nosema spp. yükünün kolonilerin kışlama kaybı üzerine doğrudan etkisi olmadığ görülmektedir. Porrini ve ark. (2011) polenle beslenen arıların Nosema spp. yükünün, yüksek fruktozlu misır şurubu ve soya kaynaklı proteinden oluşan daha az besleyici gıdalarla beslenenlerde daha fazla olduğunu bildirmişlerdir. Yazarlar ayrıca polen tüketim seviyesine göre Nosema spp. yükünün değiştiğini rapor etmişlerdir. Benzer şekilde Fleming ve ark. (2015) tarafindan yürütülen çalışmada da tüketilen polen seviyesinin Nosema spp. düzeyini arttırdığı ifade edilmektedir. Jack ve ark. (2015) ise en yoğun Nosema spp. yükünün besin kalitesinin (polen) en iyi olduğu grupta bulunan arılarda olmasına rağmen bu kolonilerde kıș kaybının gerçekleșmediğini ifade etmişlerdir. Degrandi-Hoffman ve ark. (2016), yapmış oldukları çalışmada ise doğal tarlacılık faaliyetini sürdüren bal arısı kolonilerinin, protein takviyeleri ile beslenenlere oranla daha düşük 
patojen yükleri olduğunu ve kıştan kuvvetli çıktıklarını bildirmişlerdir.

Tüm canlılarda olduğu gibi arıların da dengeli ve yeterli düzeyde beslenmesi gerekmektedir. Yetersiz beslenme bağışıklığın düşmesine, stresin artmasina ve koloni kaybina neden olabilmektedir. Kolonide kuluçka faaliyetlerinin devamlılığı ve genç bireylerin gelişimi için proteine, yani polene

\section{LITERATÜR LISTESI}

Adolfo, L. 1985. Normas analíticas do Instituto Adolfo Lutz. Métodos químicos e físicos para analise de alimentos. 2 ed. São Paulo. 1. 583p.

Akyol, E., D. Özkok, C. Öztürk ve A. Bayram. 2005. Bazı saf ve melez bal arısı (Apis mellifera l.) kolonilerinin oğu eğilimi, yaşama gücü, kışlama yeteneği ve petek işleme etkinliklerinin belirlenmesi üzerine bir araştırma Uludağ Arıcılık Dergisi 5 (4): 162-166.

Akyol, E., H. Yeninar, N. Sahinler ve A. Güler. 2006. The effects of additive feeding and feed additives before wintering on honey bee colony performances, wintering abilities and survival rates at the East Mediterranean region. Pakistan Journal of Biological Sciences 9 (4): 589-592.

Anonymous. 2018. Office International Des Epizooties (OIE). Nosemosis of honey bees. Chapter 3.2.4. World Organisation for Animal Health [www document]. https://www.oie.int/fileadmin/Home/eng/Health_standar ds/tahm/3.02.04_NOSEMOSIS_FINAL.pdf

Brodschneider, R., and K. Crailsheim. 2010. Nutrition and health in honey bees. Apidologie 41 (3): 278-294.

DeGrandi-Hoffman, G., Y. Chen, R. Rivera, M. Carroll, M. Chambers, G. Hidalgo, and E. W. De Jong. 2016. Honey bee colonies provided with natural forage have lower pathogen loads and higher overwinter survival than those fed protein supplements. Apidologie 47 (2): 186-196.

Dolezal, A. G., and A. L. Toth. 2018. Feedbacks between nutrition and disease in honey bee health. Current opinion in insect science 26: 114-119.

Doğaroğlu, M. 1981. Türkiye'de yetiştirilen önemli arı 1rk ve tiplerinin "Çukurova Bölgesi" koşullarında performanslarının karşılaștırılması. Çukurova Üni. Zir. Fak. Adana. Doktora Tezi Çukurova Üniversitesi Yıllığı 13 (3-4): 46-60.

Doğaroğlu, M., M. Özder ve C. Polat. 1986. Trakya Bölgesi Koşulları İçin En Uygun Bal Arısı (Apis mellifera L.) Genotipini Belirleme Çalıșmaları. Türkiye Bilimsel ve Teknik Araştırma Kurumu Veteriner ve Hayvancılık A grubu. Proje no: VHAG-619. gereksinim vardır. Son zamanlarda polen yerine yaygın olarak ikame arı kekleri kullanılmaktadır. Yapılan çalışmalarda, bazı protein kaynaklarının polen kadar olmasa da arı beslenmesinde olumlu etkiler gösterdiği ortaya konmakla beraber, kullanılan hazır keklerin besin içeriklerinin koloni ihtiyacını tam olarak karşılayacak düzeyde olmadığ görülmektedir.

Doğaroğlu, M. 1987. Türkiye için ideal bir sistem. Paket arıcılığı. Hasad Dergisi 23: 13-15.

Doğaroğlu, M., ve T. Ortaç. 1992. Bal arısı (Apis mellifera 1.) kolonilerinde polen üretiminin kuluçka üretimi ve oğul eğilimi üzerine etkileri. T.Ü. Tekirdağ Ziraat Fakültesi Dergisi 1 (2): 201-204.

Doğaroğlu, M. 2009. Modern Arıcılık Teknikleri. 270 s. Koridor Matbacılık, Tekirdağ. ISBN 975-94210-0-3.

El-Wahab, T. E. A., A. M. M. Ghania, and E. W. Zidan. 2016. Assessment a new pollen supplement diet for honey bee colonies and their effects on some biological activities. International Journal of Agricultural Technology 12 (1): 55-62.

Eshbah, H. M., A. A. Mohamed, A. R. Hassan, M. E. Mahmoud, and M. M. Shaban. 2018. Efficiency of feeding honey bee colonies, Apis mellifera L., with mixture of natural products and sugar syrup on brood and adult population. Scientia 21 (1): 14-18.

Firatlı, Ç. ve M. Karacaoğlu. 1995. Anadolu Arisinin Seleksiyonla Islahı Olanakları. Tübitak VHAG- 939 no'lu proje. Ankara, $80 \mathrm{~s}$.

Fleming, J. C., D. R. Schmehl, and J. D. Ellis. 2015. characterizing the impact of commercial pollen substitute diets on the level of Nosema spp. in honey bees (Apis mellifera L.). PLoS ONE 10 (7): e0132014. doi:10.1371/journal.pone.0132014

Fries, I. 1993. Nosema apis: A parasite in the honey bee colony. Bee World 74 (1): 5-19.

Fresnaye, J., and Y. Lensky. 1961. "Methods d'Apperaciation des Surfaces de vain dans les Colonies d'Abeilles", Ann. Abeille 4 (4): 369-376.

Fuenmayor, C. 2009. Bioprocess application in bee pollen development of a protein nutritional supplement. Universidad Nacional de Colombia, Bogotá, Colombia.

Gemeda, T. K. 2014. Testing the effect of dearth period supplementary feeding of honeybee (Apis mellifera) on brood development and honey production. Int. J. Adv. Res. (2): 319-324.

Güler, A., A. C. Gürel ve İ. Durmuş. 1999. Bal Arısı (Apis mellifera L.)'nda Fizyolojik ve Davranış Karakterlerini Belirleme Yöntemleri. Türkiye'de Arıcılık Sorunları ve 1. Ulusal Arıcılık Sempozyumu 28-30 Eylül 1999. Kemaliye/Erzincan. s. 180-188. 
Huang, Z. 2012. Pollen nutrition affects honey bee stress resistance. Terrestrial Arthropod Reviews 5 (2): 175189.

Irandoust, H., and R. Ebadi. 2013. Nutritional effects of high protein feeds on growth, development, performance and overwintering of honey bee (Apis mellifera L.). International Journal of Advanced Biological and Biomedical Research 1 (6): 601-613.

Jack, C., R. Sagili, and S. S. Uppala. 2015. Investigating effects of pollen nutrition on Nosema ceranae infection and persistence in honey bee colonies. Section II: Bees and Pollinators 29-31.

Kaftanoğlu, O., U. Kumova ve Y. Bek. 1993. Gap Bölgesinde Çeşitli Bal Arısı Irklarının Performanslarının Saptanması ve Bölgedeki Mevcut Arı Irklarının Islahı Olanakları. Ç. Üniversitesi. Ziraat Fak. Güneydoğu Anadolu Projesi (Gap) Tarımsal Araștırma İnceleme Ve Geliştirme Paketi. Ç.Ü. Zir. Fak. Genel Yay. No: 63 Gap Yay. No:74. Adana, 50s.

Kandemir, İ. 2004. Paket arıcılık ve paket arıcıllğın kurulması. Uludağ Arıcılık Dergisi 4 (3) : 100-103.

Koru, B. Y. 2018. Bal arılarında (Apis mellifera) beslenme farklılığının yaşam uzunluğu, gelişme, davranış (Amılp$1, V g)$ Ve Nörotransmitter Salınımını Düzen-leyen (Brp) genlerindeki etkilerinin araştırılması. Yüksek Lisans Tezi. Namık Kemal Üniversitesi Fen Bilimleri Enstitüsü, Tekirdağ. 65 sayfa.

Kumar, R., R. C. Mishra, and O. P. Agrawal. 2013. Effect of feeding artificial diets to honey bees during dearth period under Panchkula (Haryana) conditions. Journal of Entomological Research 37 (1): 41-46.

Mata, M. 2018. Two approaches to protecting bees: Bee nutrition in a changing climate and community outreach as a tool for bee conservation. thesis submitted to the Graduate Faculty of North Carolina State University in partial fulfillment of the requirements for the degree of Master of Science, Raleigh, North Carolina.

McAulay, M. 2018. Examining the Impact of Pollen Diet Composition on Bee Development and Lifespan (Doctoral dissertation, Université d'Ottawa/University of Ottawa).

Nicolson, S. W., S. D. Neves, H. Human, and C. W. Pirk. 2018. Digestibility and nutritional value of fresh and stored pollen for honey bees (Apis mellifera scutellata). Journal of insect physiology 107: 302-308.

Öder, E. 1997. Uygulamalı Ana Arı Yetiștiriciliği. İstanbul.

Peters, L., K. Zhu-Salzman, and T. Pankiw. 2010. Effect of primer pheromones and pollen diet on the food producing glands of worker honey bees (Apis mellifera L.). Journal of insect physiology 56 (2): 132-137.
Porrini, M. P., E. G. Sarlo, S. K. Medici, P. M. Garrido, D. P. Porrini, and N. Damiani. 2011. Nosema ceranae development in Apis mellifera: influence of diet and infective inoculum. Journal of Apicultural Research 50 (1): 35-41.

Rice, R. N. 2001. Nosema Disease in Honeybees Genetic Variation and Control. Rural Industries Research and Development Corporation, RIRDC Publication, UK.

Saffari, A., P. G. Kevan, and J. L. Atkinson. 2010. Palatability and consumption of patty-formulated pollen and pollen substitutes and their effects on honeybee colony performance. J. Apic. Sci. 54 (2): 63-71.

Sena, S., L. Sena, and A. Hoda. 2017. Bee-colonies performance evaluation based on the application of two levels Feedbees' concentration. Albanian Journal of Agricultural Sciences, Special Edition: 341-346.

Shumkova, R., I. Zhelyazkova, S. Lazarov, and R. Balkanska. 2017. Effect on the chemical composition of the body of worker bees (Apis mellifera L.) fed with stimulating products. Macedonian Journal of Animal Science 7 (12): 129-135.

Sihag, R. C., and M. Gupta. 2013. Testing the effects of some pollen substitute diets on colony build up and economics of beekeeping with Apis mellifera L. Journal of Entomology 10 (3): 120-135.

Somerville, D. 1999. Wintering bees. Agnote DAI/121. NSW Agriculture.

Somerville, D. 2000. Honey bee nutrition and supplementary feeding. Agnote DAI/178. NSW Agriculture.

Somerville, D. 2005. Nosema disease in bees. Agnote DAI/124. NSW Agriculture.

Steel, R. G. D., and J. H. Torrie. 1980. Principles and Procedures of Statistics. Second Ed. McGraw-Hill Book Company Inc., New York.

Şahinler, N. ve Ş. Kaya. 2001. Bal arısı kolonilerini (Apis mellifera L.) ek yemlerle beslemenin koloni performansı üzerine etkileri. Mustafa Kemal Üniv. Zir. Fak. Derg. 6 (1-2): 83-92.

Yang, W., Y. Tian, M. Han, and X. Miao. 2017. Longevity extension of worker honey bees (Apis mellifera) by royal jelly: optimal dose and active ingredient. Peer J. 28; 5.e3118. doi: 10.7717/peerj.3118.

Yurtsever, N. 1984. Deneysel Istatistik Metotları. Köy Hizmetleri Toprak ve Gübre Arş. Enst. Müdürlüğü Yavınları Genel Yayın No. 121 Ankara.

Yücel, B. ve M. Kösoğlu. 2011. Ege Bölgesi'nde Muğla ekotipi ve italyan melezi bal arılarının kimi performans özellikleri bakımından karşılaştırılması. Kafkas Univ. Vet. Fak. Derg. 17 (6): 1025-1029. 